\title{
Social and sustainable: exploring social media use for promoting sustainable behaviour and demand amongst Indian tourists
}

\author{
Shruti Gulati
}

\author{
Department of Commerce, Delhi School of Economics, University of Delhi, \\ New Delhi, India
}

\begin{abstract}
Purpose - While researchers have studied the impact of social media on tourist behaviour Milano et al. (2011) and Hays et al. (2013), very few studies have explored the impact of social media on sustainable tourism, and thus, it can be said to be in its "infancy" (Han et al., 2017). There exists a "knowledge gap" not just with tourists but also with researchers, as the issue on sustainable tourism consumption is "rarely investigated directly in tourism researches" or consumer behaviour studies, and there is often discrepancy in literature on the issue (Cohen et al., 2014; Bray et al., 2011). While the potential for social media in promoting sustainable tourism is known considering the use of it for socialisation and knowledge sharing, empirical researches to make in depth enquiry on the same is "rare" (Ali and Frew, 2010; Sarkar et al.,2014). Also, the differences between markets for sustainable tourism amongst different markets needs to explored further (Weber, 2019). The purpose of this study is to fill this gap by proposing a conceptual framework and empirically testing how social media can be used to generate and promote sustainable tourism demand among through evidences from Indian tourists. RQ1: what are the key drivers to use social media by sustainable tourists? RQ2: can social media promotions help sustainable demand generation through spreading awareness and connecting fellow sustainable tourists? Design/methodology/approach - A total of 350 Indian tourists were reached through Google forms distributed through various channels, amongst which 265 responded with a response rate of $75.7 \%$. The data were coded and checked for any outliers and missing values. To avoid any biases, incomplete forms were not counted and after data cleaning, 250 respondents were found to be appropriate with all the responses. Analysis of demographic and travel profile was done through SPSS 22 to check variances in the groups, frequencies and chi square values were calculated. Since this is an exploratory study, the aim was more on prediction rather than model confirmation, thus the technique used and found to be appropriate was partial least squares structural equation modelling (PLS-SEM).

Findings - Variances of social media were used in the demographic groups and found that there was no significant difference found as per age and education. Even variation of travel habits was found to be not significant with social media use. It can be seen that social media promotion activities indeed create awareness amongst people about sustainability; creating awareness about sustainability indeed leads to connecting green tourists together. On the other hand, social media promotional activities may not necessarily connect potential green tourists together; awareness positively impacts the generation of sustainable demand is also supported. It can be seen that merely connecting potential green tourists does not necessarily create demand. Social media promotion activities are indeed instrumental in creating a sustainable demand amongst tourist.

Research limitations/implications - This study takes into account the informational and environmental knowledge aspect of sustainable behaviour adoption by green tourists (Swarbrooke and Horner, 2007; Miller, 2003; Chan et al.,2014). This study draws implications based on the behaviour of Indian tourists and thus, the generalisation to other countries may not be as accurate as Indians differ culturally from the world at large. Even though the study involves different age groups, the mean age is of younger Indian tourists, which is also often considered as the most active users of social media and thus likely to be impacted more. Also, it is believed that these younger green consumers who are already inclined towards sustainability tend to seek more information on ethical issues (Finney, 2014). The sample size of the study is very small $(n=250)$ and was only
\end{abstract}

(C) Shruti Gulati. Published by Emerald Publishing Limited. Published in International Hospitality Review. This article is published under the Creative Commons Attribution (CC BY 4.0) licence. Anyone may reproduce, distribute, translate and create derivative works of this article (for both commercial and non-commercial purposes), subject to full attribution to the original publication and authors. The full terms of this licence may be seen at http://creativecommons.org/licences/by/4.0/legalcode

Received 9 December 2020 Revised 25 January 2021 Accepted 19 February 2021 
IHR

36,2

checked for variation amongst gender and profession; other aspects such as income and employment (Swarbrooke and Horner, 2007; Miller, 2003) have been kept out of the study and thus not included as a part of demographics. More demographic characteristics can be taken into account to study if they play a mediating role in generating sustainable demand as a part of the analysis of this conceptual framework proposed.

Practical implications - Internet allows users to obtain information about products and brands to its users through various social media such as blogs, forums, wikis content sharing, etc. (Hennig-Thurau and Walsh, 2003; Reilly and Weirup, 2010). Strategies can thus be formulated to target sustainable tourists with sustainable destinations and amenities, so as to attract those tourists who appreciate and commit to the cause of sustainability (López-Sánchez and Pulido-Fernández, 2016). Using social media as a promotion tool can help in educating customers (Xiang and Gretzel, 2010) on the various sustainable tourism services they intend to offer, as the results supports the use of social media promotion for generating sustainable demand amongst the tourists. Also, the sustainable tourism providers can make use of promotional activities focussing on building online pro environmental tourist-based communities using the user generated contents which can positively lead to adoption of collective social behaviour and sustainable practices (Han et al., 2017). Specifically, the use of short interactive messages can be used for social media promotions, so as to increase "organisation prominence" amongst the green target groups online (Strähle and Gräff, 2017). While it was noted that different markets react differently to the idea of sustainability, and thus, different markets need to be explored deeper (Weber, 2019); this study attempts to provide a perspective of Indian tourists which not just adds to the literature on Indian tourist behaviour but also provides a viewpoint of the Asian tourists. It also enriches the existing literature on the use of AIDA model for services and tourism specifically which as a theoretical base is unexplored.

Originality/value - The study adds to the rising interest in understanding the behavioural changes in tourists (Hall, 2016) and provides insights on "the versatility of the topic of relationship between sustainable tourism and marketing" (Font and McCabe, 2017). While ethical consumption is essential to preserve resources, the study of this area of consumer behaviour is "under examined", as majority studies focus on products, very few studies elucidate on encouraging it through social marketing (Newholm and Shaw, 2007). Thus, this study attempts to fill the gap in the literature by proposing a framework for generating sustainable demand amongst tourists so that they are inclined socially and sustainably both through the use of social media. It is often noted that tourists are unwilling to change their travel behaviour as a result of lack of awareness or due to hesitance of sacrificing (Juvan and Dolnicar, 2014; Miller et al., 2010). This study provides empirical evidence that supports the awareness of sustainability as a means of generating sustainable demand amongst tourists. Knowledge regarding tourism demand helps in the further development of tourism products and its marketing initiatives (Weber, 2019). Thus, it allows tourism players to understand that Indian tourists are open to sustainable tourist practices if enough information is provided to them.

Keywords Sustainability, Tourist, User generated content (UGC), PLS-SEM, Awareness,

Consumer behaviour, Social media

Paper type Research paper

\section{Introduction}

We are living on this planet as if we had another one to go to. - Terry Swearingen

Since childhood, we have been taught that whatever we have received from our ancestors, it should be respected and preserved as a blessing since we are gifted. At the same time, we should try and take forward the legacy by providing the same to the future generations, so that they also cherish it in a similar manner. But when it comes to the planet and its species, we often tend to forget this and continue using resources in utmost selfish fashion without thinking of what repercussions it may have for the present generation let alone the future. Very often we hear about global warming and the rising temperatures, the depleting forests and the wildfires, natural calamities and disastrous mis-happenings, the roots of which is the neglection of the concept of sustainability. The awakening for it is often procrastinated or unknown is still a question to ponder deep over considering how conveniently it is turned a blind eye to.

Sustainability is often used interchangeably with words like "green" and "environment friendly" (Peattie, 1995). Sustainable tourism is a concept that encourages the utilisation of tourism services while respecting people, tourists, culture, heritage and the environment (Fien et al., 2010). Sustainable tourism practices are not an unknown concept for Indians. Sustainability has been an important aspect of the ASEAN Tourism Strategic Plan 
(2011-2015), which focussed on developing a plan to involve residents for sustainability and responsible tourism amongst ASEAN tourism Industry (UNWTO, 2010), followed by Tourism Strategic Plan (2016-2025), aiming at making ASEAN tourism more "inclusive," "green," and "knowledge-based." Also, empirical evidence was seen in the study by Institute for Tourism ITW of the Lucerne University of Applied Sciences and Arts (Wehrli et al., 2011); Indians were found to be considering "sustainability" as one of the top three factors for hotel bookings. This response $(41.3 \%)$ was noted as much higher in comparison to Western industrialised countries. But, very often sustainability is not the first choice of travellers (Wehrli et al., 2011), and only a distinguishing criterion while other factors of travel buying decisions were similar (Deloitte, 2011). This is also why tourism industry has been referred to as "far from sustainable". The topic of sustainability, environmental awareness has become a part of "fashionable lifestyles" (Grant, 2007). In reality, sustainability is a dire need in today's time.

In the era of social media, there is an ease to inculcate any change through mass audiences and minimal efforts, this is because it has the "ability to reach consumers worldwide" (Reilly and Hynan, 2014). The magic of user generated content takes a holistic approach towards sustainable behavioural practices making it an instrumental step towards sustainable tourism. Social media use in tourism is now a common trend and is visible when tourists buy or book travel products (Buhalis and Law, 2008; Jun et al., 2007), or when they wish to evaluate or be advised on travel plans (Ayeh, 2015) or to communicate with their social circle (Gossling and Stavrinidi, 2015).

The relevance of social media advertising in tourism has been previously noted due to the "information intensive" nature of the industry, and thus can be said social media promotion helps in information dissemination to tourists (Hays et al., 2013). Not just tourists, businesses are also increasing their usage and dependency on IT and social media for managing and marketing their travel and tourism businesses and sometimes to "communicate favourable consumer opinion" (Hays et al., 2013; Mauri and Minazzi, 2013). Studies have found the user generated content on social media to persuade beliefs, attitudes and their behaviours (Batat and Prentovic, 2014; Buhalis and Licata, 2002; Sparks et al., 2013). Also, social media has created social groups on digital platforms, to which users seek alignment and reciprocity to (Chan et al., 2014) and end up making social connects online. Thus, social media has become a common tool for tourism stakeholders to achieve their objectives because of the features it provides starting from attracting tourists to newer destinations to transforming the scope of the industry to sustainable tourism.

While researchers have studied the impact of social media on tourist behaviour such as Milano et al. (2011) and Hays et al. (2013), very few studies have explored the impact of social media on sustainable tourism and thus it can be said to be in its "infancy" (Han et al., 2017). There exists a "knowledge gap" not just with tourists but also with researchers, as the issue on sustainable tourism consumption is "rarely investigated directly in tourism researches" or consumer behaviour studies, and there is often discrepancy in literature on the issue (Cohen et al., 2014; Bray et al., 2011). While the potential for social media in promoting sustainable tourism is known considering the use of it for socialisation and knowledge sharing, empirical researches to make in depth enquiry on the same is "rare" (Ali and Frew, 2010; Sarkar et al., 2014).

Also, the differences between markets for sustainable tourism amongst different markets needs to explored further (Weber, 2019). This study seeks to fill this gap by proposing a conceptual framework and empirically testing how social media can be used to generate and promote sustainable tourism demand among through evidences from Indian tourists.

This study aims to answer the following research questions:

$R Q 1$. What are the key drivers to use social media by sustainable tourists?
Social and sustainable 
IHR

36,2
$R Q 2$. Can social media promotions help sustainable demand generation through spreading awareness and connecting fellow sustainable tourists?

\section{Theoretical background}

Sustainability, tourism and social media

Sustainability. Sustainability is considered as the principle for economic development, the essence of which is that it does not trade off human and ecological advancement. Ideas such as futurity, equity and holism have found their space in the sustainability concepts.

In other words, sustainability is utilizing resources and attractions in a manner that they can be used without comprise by future generations as well (UNWTO, 2000, 2010).

Environmental sustainability. UNWTO (2005) have defined environmental sustainability as "Make optimal use of environmental resources that constitute a key element in tourism development, maintaining essential ecological processes and helping to conserve natural heritage and biodiversity."

Tourism. "Tourism comprises the activities of persons travelling to and staying in places outside their usual environment for not more than one consecutive year for leisure, business and other purposes" (UNWTO, 2017).

Sustainable tourism. World tourism organisation has defined sustainable tourism as "tourism that meets the needs of present tourists and host regions while protecting and enhancing opportunities for the future" (WTO, 2001).

The focus of sustainable development in tourism is to manage resources in a manner that economic, social and aesthetic needs are fulfilled in a manner that "cultural integrity, essential ecological processes, biological diversity, and life support systems" are managed (Simpson et al., 2008).

Tourism which is experiential in nature attempts to achieve sustainability in a manner that redefines consumption of tourism services not just with great experiences but also the use of resources in a sustainable limited manner such that there is scope for recycling, efficient use of resources such as water and energy.

Social media. Social media can be defined as "a group of Internet-based applications that allow the creation and exchange of User Generated Content” (Kaplan and Haenlein, 2010). Social media is a common platform for common people with common interests, where people interact on without constraints of time and place (Weber, 2009).

Safko and Brake (2009) have defined social media as “...activities, practises and behaviours among communities of people who gather online to share information, knowledge, and opinions using conversational media. Conversational media are Webbased applications that make it possible to create and easily transmit content in the form of words, pictures, videos, and audios."

Social media marketing refers to the process that allows and empowers firms and individuals to promote their products and services through social media channels and reach mass audiences and thus tap communities that may not be reached through traditional media channels (Weinberg, 2009).

\section{Social media in tourism}

Various stakeholders such as consumers, marketers and hospitality service providers use different social media for different purposes. Social media use during travel has become a common practice amongst tourists. This is due to the massive content that users get while travelling which often leads to a feeling of belonging and sharing amongst the travellers, and the ease of mass reach and free distribution gains them popularity. Social media is used all 
throughout the journey of travel by both the traveller and the travel and tourism service providers. The most prominent uses of social media in tourism are information exchange, publicity and promotion, trip planning and decision-making and social sharing. (Buhalis and Law, 2008; Gossling and Stavrinidi, 2015). Social media also allows tourists to not only stay in touch with their friends and family (Bach and Stark, 2004) but also transform relationships and create "collective intelligence" (Hvass and Munar, 2012). It helps and allows users to create a community where they can build social interactions with fellow travellers, along with a bond built on trust and verification (Munar, 2011).

The primary uses of social media in tourism can be clubbed as per their utility such as functional, social, psychological, socio-psychological, as well as hedonic (Chung and Buhalis, 2008; Parra-Lopez et al., 2011; Xiang and Gretzel, 2010). These are shown in Table 1.

\section{Social media for promoting sustainable tourist behaviour}

The sustainable tourism literature witnesses several interchangeable references for people having an affinity towards sustainable consumption. These are green (Swarbrooke and Horner, 2007), ethical (Weeden, 2013), conscious (Higgins-Desbiolles, 2017) or sustainable consumers (Wehrli et al., 2011). Sustainable tourist is a person who is travelling outside his place of residence for travel or leisure or business, but has concern for the society and its resources. Some key areas of concern of a green tourist are shown in Figure 1

Swarbrooke and Horner's (2007) and Miller's (2003) propounded that green behaviour can be determined by three major factors, i.e. information obtained from various media channels

\begin{tabular}{|c|c|c|c|}
\hline Benefit & Author & Utility & \\
\hline Functional & Chung and Buhalis (2008) & Decision Making & \\
\hline Hedonic & Chung and Buhalis (2008) & Social Sharing/Interactions & Table 1. \\
\hline Socio psychological & Parra-Lopez et al. (2011) & Identity and Belongingness & Uses of social media in \\
\hline Source(s): Author's own & & & tourism \\
\hline
\end{tabular}

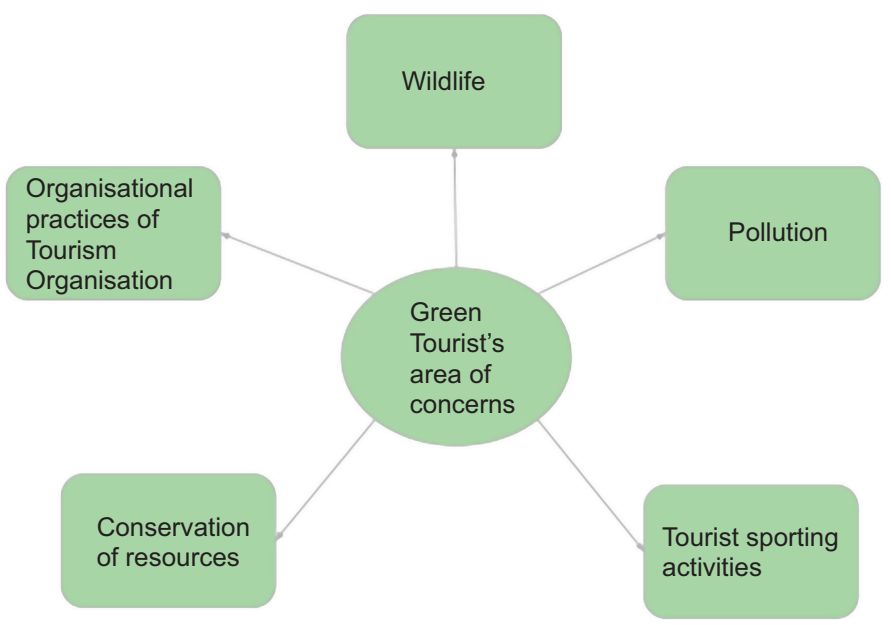

Source(s): Author's own (adapted from Swarbrooke and Horner, 2007)

Figure 1. Green Tourist's areas of concern 
IHR

36,2

\section{8}

and pressure groups, the disposable income and employment (see Figure 2). Social media tends to focus on the information aspect. While Chan et al. (2014) in their study noted that there are three major triggers of adopting green practices in tourism, i.e. "environmental knowledge, environmental behaviour and environmental concern".

For consumers to make sustainable choices of consumption and adopt green products, it is imperative for them to be marketed successfully (Rex and Baumann, 2007). "The media is widely acknowledged to play an important part in gaining public support for sustainability initiatives" (Seip et al., 2006 as cited in Kolandai-Matchett, 2009, p. 1)) due to the role it has in spreading education and information quickly. Thus, as a tool for sustainability communication, social media facilitates promoting and engaging users towards sustainable consumption in this digital age (Diaz, 2015; Johnson, 2014; Zolkepli and Kamarulzaman, 2015).

\section{Why does a sustainable tourist use social media?}

The following are a sustainable tourist's key drivers to use social media:

Socialisation. Socialisation comprises of sharing of experiences and maintaining social interaction with peers and fellow sustainable tourists over social media. This serves as an important reason for social media popularity with tourists. (Parra-Lopez et al., 2011; Sarkar et al., 2014). Various authors have studied how socialisation leads to satisfaction and in turn enhances tourist's experiences of the overall sustainable tourism (Sarkar et al., 2017). Social media helps the sustainable tourists to have greater and long-lasting tourist experiences even after they have returned from the trip (Sarkar et al., 2014, 2017)

Dissemination of knowledge. Learning forms an integral element of tourism (Falk et al., 2012). Social media in today's era is replacing the traditional travel agents where customers are empowered to plan their trips on their own. Social media thus helps sustainable tourists to disseminate information for trip research purposes with other tourists who may be keen in practising sustainable tourist behaviour. Due to a mass audience and global reach, social media allows sustainable tourists to share their expertise with multiple people simultaneously which may encourage other travellers too.

Reputation. Social media is a space for ample attention; it is a virtual world in itself. Users now a days compete for attention which depends on the content that they post (Garcia et al., 2013). Sharing of experience can give the members recognition and an incentive to others (Cummings et al., 2002). The outcome of socialisation through social sharing is gaining respect and enhancing reputation for those things that are displayed on social media. Indulging in sustainable practices is a symbol of a good deed that a tourist does towards the society. Hence, he is prompted to post the same on social media, so as to get praise and recognition in the virtual and the real world.

\section{Conceptual model}

For the purpose of this study, two fundamental theories have been kept as a basis of the conceptual framework that is proposed and tested empirically. These are:

\section{The social information processing theory and tourist behaviour}

Developed in 1992, by Joseph Walther, this theory discusses the relevance of relationships in a computer mediated environment such as chats via instant messaging, emails, texts, etc. for not so traditional face to face communication. This theory elaborates how social media helps in processing interpersonal influence. The basic premise on which this is build is that "meaning is socially constructed, and social environments offers an important source of information and cues about individual's behaviour and perceptions" (Michaelson and Stacks, 2011). 
The theory indicates how over time computer mediated communication can be as effective as face-to-face interaction over time and affinity can be developed.

Social values in terms of preferences, principles and virtues are held commonly and co-created by the social group members; these are vital for the adoption of sustainability as it is closely linked to behaviour (Chan et al., 2012; Manfredo et al., 2016). Social media offers a digital community to the users to share their experiences, perceptions that also includes social and ecological activities, thus they are motivated and affected by such interactions of others members (Ames and Naaman, 2007).

Travel communities such as PlanetA and Ecoclub are social media platforms of travel enthusiast that have a sustainable approach to tourism, which unites likeminded people and motivates newer participants. Social relationships build through communication on social media prompts tourists to be more cautious in their usage of resources and planet at large.

\section{The AIDA model}

Widely used in advertising, the AIDA model includes four major stages i.e. awareness, interest, desire and action (Lewis, 1989). Started as a theory aimed at the products industry, soon AIDA model founds its utility in service industry such as tourism (Rawal, 2013). The first stage begins with getting the consumer have a closer look towards a product through awareness generation which is done to make the consumer realise the existence and utility of the product. In today's tech savvy era, social media promotion is the most instrumental for creating awareness. The second stage involves attracting the consumer towards the product or service to keep him interested in it (Wijaya, 2015). This can also be done through various marketing campaigns on social media which keeps the potential customers hooked. The third stage involves creating a desire of the consumer to actually purchase the product or avail the service. The fourth stage involves the completion of buying cycle with the action of actual purchase.

Keeping in mind that the AIDA model has the same importance for tourism sector (Kojima et al., 2010); Kotler et al. (2005) have explained that AIDA can also be said as the process of awareness of a product or a service, the following of interest based on the benefits of

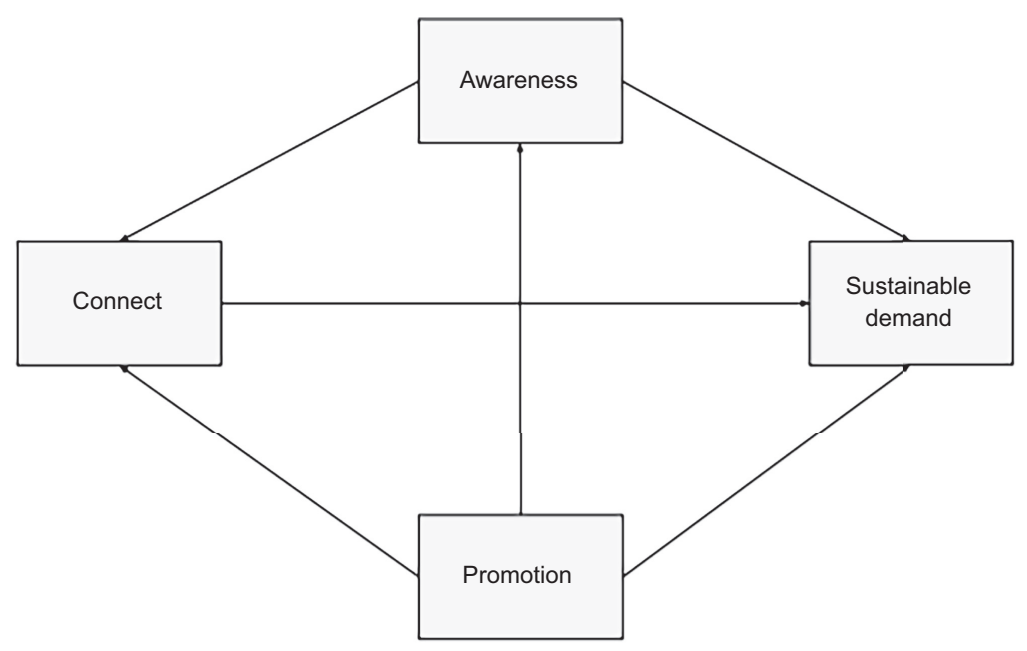

Source(s): Author's own
Social and sustainable

379
Figure 2.

Conceptual model to promote sustainable tourist behaviour through social media 
IHR

36,2

\section{0}

consumption, the emergence of emotional desire and the final action of purchase or enquiry. Adapting the AIDA model for promoting sustainable behaviour, following is the proposed model that can help promote sustainable demand amongst sustainable tourist with the help of social media channels.

\section{Variables and hypotheses construction}

The following are the variables of this study:

\section{Social media promotion (Promotion)}

Social media has been studied as an interactive channel of promoting "environmentalist ideology" and social change (Luck and Ginanti, 2013); it has also been found to be positively promoting sustainable consumption practices and lifestyles (Luck and Ginanti, 2013). In terms of tourist behaviour, it is found to be impacting tourists towards sustainable or eco activities and responsible tourist behaviours (Batat and Prentovic, 2014). Also, online messages have been found to be more persuasive than the routine tour operators for tourists (Hardeman et al., 2017). For example, Kane et al. (2012) found out Facebook to be an innovative environment for enhanced sustainable behavioural intentions. Also, the use of tags, hashtags, "likes" and ratings help as an important source of information about natural environment and culture creation (Derungs and Purves, 2016; Guerrero et al., 2016; Gliozzo et al., 2016; Hausmann et al., 2018).

\section{Creating awareness about sustainability (Awareness)}

The first step to adopting change is to be aware of the problem and the need to change. Social media helps being an open platform and having a massive global reach provides the space. Recent decades have witnessed a rise in environmental consciousness; a lot of it is attributed to awareness and media pressure (Charter, 1992; Tapon and Leighton, 1991).

Stakeholders such as the government, international organisations and hospitality industry players use it as a means to create awareness of the concept of sustainability in the tourism sector. Sustainable practices such as reusable materials, conservation of water and usage of organic food are some concepts that have been introduced online through social media. This not just allows the organisations to introduce sustainability but also allows them to show their responsible presence (Rasche, 2010). Social media allows the flexibility to cover varied areas of concerns globally such as ecological irresponsibility, extinction and endangered species, etc.

H1. Social media promotion activities positively impact awareness about sustainability amongst tourists.

\section{Building a connect (Connect)}

Social media allows likeminded people to connect with each other through social channels such as blogs, discussion forums, etc.; this "social connectedness" often leads to users building a social capital (Germann Molz, 2012; Gossling and Stavrinidi, 2015). Virtual communities have been active in stimulating sustainable behaviour (Langley and van den Broek, 2010); some that allow sustainable tourists to connect are EcoClub and PlanetA. Thus it helps to empower tourists and sustainable communities to become more assertive (Johnston and Tyrrell, 2005). Discussions centric to ecology, ecotourism and environment as a whole allow existing and potential tourists to bond (Sarkar et al., 2014, 2017). Social media has the transformative power to build connections amongst users with knowledge sharing interactions (Ahuja and Galvin, 2003). Also, these interactions build connections of people with similar needs, tastes and backgrounds which further facilitate the right information reaching the right consumers (Pentina and Tarafdar, 2014). 
H2. Social media promotion positively influences building a connection amongst tourists.

H3. Awareness about sustainability positively influences building a connection among tourists.

Generate sustainable demand of tourism products (sustainable demand)

Microblogs has become a meaningful tool for eco travel companies to promote their services to sustainable tourists based on their demand and interests (Cheng et al., 2016; Lai and Shafer, 2005). They utilise multimedia such as animation and graphics to attract tourists towards sustainable demands (Zhang et al.,2011) certifications to promote nature-based products, and other environmentally safe products is used as a tactic to show authentic sustainable approach (Bustam et al., 2012). User-generated content available online acts as a great promotion tool for companies to promote their sustainable tourism services to larger audiences (Cheng et al., 2016). This in turn results in encouraging a socially and environmentally aware demand (Zapico et al., 2010).

H4. Awareness about sustainability positively impacts sustainable demand generation.

H5. Connecting sustainable tourists positively impacts sustainable demand generation.

H6. Social media promotion positively impacts sustainable demand generation.

\section{Methodology}

Following is the research methodology adopted for this study:

\section{Data and sample}

Keeping in mind the principles of consumer behaviour, a tourist is assumed as a consumer of tourism services. Integrating theories of consumer psychology and social media, an attempt has been made to develop a theoretical framework on how sustainable tourist behaviour can be promoted through social media to generate sustainable demand and variables have been identified.

Primary data have been collected through an online questionnaire distributed to Indian travellers who are Internet users. The questionnaire was divided into two parts. The first part aimed to study their demographic and travel profile, and second part focussed on their awareness and willingness to switch to sustainable tourism products.

A total of 350 Indian Tourists were reached through Google forms distributed through various channels, amongst which 265 responded with a response rate of $75.7 \%$. The data were coded and checked for any outliers and missing values. To avoid any non-response biases, incomplete forms were not counted, and after data cleaning, 250 respondents were found to be appropriate with all the responses.

\section{Scales of measurement}

All the variables were measured using a five-point Likert scale, where 1 meant "strongly disagree" and 5 meant "strongly agree". The questions were self-constructed through an in-depth literature analysis and thus, taking into account research gaps of the existing literature.

\section{Statistical techniques}

Analysis of demographic and travel profile was done through SPSS 22 to check variances in the groups; frequencies and chi square values were calculated. Structural equation modelling 
IHR

36,2

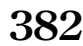

was used to study structural relationships between the variables of the model. Since this an exploratory study, the aim was more on prediction rather than model confirmation, thus the technique used and found to be appropriate was PLS-SEM. Path modelling using path coefficients has been used to test the hypothesised relationships. SmartPLS professional software v3.3.2 (Ringle et al., 2015) has been used for data analysis.

\section{Results and analysis}

First part of the survey was analysed for demographic and travel profiles. After performing analysis on SPSS 22 , it was seen that gender distribution was unbalanced with $66.4 \%$ males and $33.6 \%$ females. The mean age of the respondents was 26 , with age ranging from 25 to 35 , and the majority respondents were post graduates $(52 \%)$, followed by graduates $(24 \%)$ and senior secondary $(15 \%)$ and doctorates $(9 \%)$. For travel habits, majority of respondents travelled for weekend getaways within their native place $(42 \%)$, followed by domestic holidays (37\%) and foreign holidays (21\%). Indian traveller prefers family holidays $(61 \%)$ with spouse or relatives over holidays with friends $(28 \%)$ and solo travel in India is still a novel unexplored concept $(11 \%)$. We tested variances of social media use in the demographic groups and found that there was no significant difference found as per age $(p>0.05)$ and education $(p>0.05)$. Even variation of travel habits was found to be not significant with social media use. $(p>0.05)$.

\section{Structural equation modelling}

The technique used for studying the hypothesised relationships is PLS-SEM, as the study is exploratory and the model is just identified which makes it a suitable technique (Hair et al., 2017). SEM uses a two-step approach where all constructs of the model are measured simultaneously using measurement model and structural model analysis, and hypothesised structural relations are tested for significance (Hair et al., 2013a, b). The use of PLS-SEM allows in the development of theory and prediction of constructs (Hair et al., 2013a, b).

Measurement model results. The measurement model which is the inner model must meet the minimum requirements in terms of terms of construct reliability, outer loadings, indicator reliability and average variance extracted (AVE). These were calculated through PLS algorithm and checked with threshold limits (Hair et al., 2011; Chin, 2010; Henseler et al., 2015: Hair et al., 2017) and have been discussed as follows:

Indicator reliability. To test if the indicators are reliable, the cut-off suggested for an exploratory study is 0.4 (Stevens, 2012). Indicator loadings are calculated for all the indicators and can be seen in Table 2. As G1 is below the threshold of 0.4 (Stevens, 2012), it is eliminated from the model.

Internal consistency reliability and convergent validity. To test the reliability of the instrument, composite reliability above 0.7 is preferred (Chin, 2010; Henseler et al., 2009; Vinzi et al., 2010) and AVE above 0.5 is acceptable (Hair et al., 2014). From Table 2, we can see the criterion is met and is satisfactory (see Table 2).

Discriminant validity. To discriminate the constructs, it is important to check discriminant validity; the best method is found to be HTMT 0.9 for an exploratory research (Henseler et al., 2015) and can be seen from Table 3 which is satisfactory.

Structural model results. Structural model represents the outer model and tests the structural relationships of the constructs which help in analysing the interrelationships through path coefficients, collinearity and their predictive relevance in terms of $R^{2}$ and $Q^{2}$ (Hair et al., 2013a, b).

Following are the structural model results:

Path coefficients and $t$ values. To start with, collinearity of all the indicators of the constructs were assessed, and VIF was found to be less than cut-off value of 5 ; tolerance level 
0.2 (Hair et al., 2014). After running bias-corrected and accelerated (Bca), bootstrap on 5,000 samples were checked for $t$ values above 1.96 for a two tailed test of $95 \%$ significance level, and path coefficients were obtained and checked for $p<0.05$. (refer Table 5).

\begin{tabular}{|c|c|c|c|c|c|c|}
\hline & & Loadings & Cronbach's alpha & rho_A $A$ & $\mathrm{CR}$ & AVE \\
\hline \multirow[t]{4}{*}{ Awareness } & $\mathrm{A} 1$ & 0.708 & \multirow[t]{4}{*}{0.692} & \multirow{4}{*}{0.692} & \multirow{4}{*}{0.811} & \multirow[t]{4}{*}{0.517} \\
\hline & $\mathrm{A} 2$ & 0.726 & & & & \\
\hline & A3 & 0.747 & & & & \\
\hline & $\mathrm{A} 4$ & 0.695 & & & & \\
\hline \multirow[t]{4}{*}{ Connect } & $\mathrm{C} 1$ & 0.904 & \multirow[t]{4}{*}{0.773} & \multirow[t]{4}{*}{0.822} & \multirow[t]{4}{*}{0.853} & \multirow[t]{4}{*}{0.599} \\
\hline & $\mathrm{C} 2$ & 0.849 & & & & \\
\hline & C3 & 0.746 & & & & \\
\hline & $\mathrm{C} 4$ & 0.55 & & & & \\
\hline \multirow[t]{3}{*}{ Sustainable demand } & G1 & $0.018^{*}$ & \multirow{3}{*}{0.651} & \multirow{3}{*}{0.629} & \multirow{3}{*}{0.711} & \multirow[t]{3}{*}{0.577} \\
\hline & $\mathrm{G} 2$ & 0.953 & & & & \\
\hline & G3 & 0.499 & & & & \\
\hline \multirow[t]{2}{*}{ Promotion } & P1 & 0.958 & \multirow[t]{2}{*}{0.606} & \multirow[t]{2}{*}{0.887} & \multirow[t]{2}{*}{0.767} & \multirow[t]{2}{*}{0.635} \\
\hline & P2 & 0.594 & & & & \\
\hline
\end{tabular}

Note(s): *Less than 0.4 and hence eliminated

Table 2.

Source(s): Author's own

Reliability statistics

\begin{tabular}{llll}
\hline Awareness & Connect & Sustainable demand & Promotion \\
\hline
\end{tabular}

Awareness

Connect

Sustainable demand

0.833

Promotion 0.657

0.576

$0.657 \quad 0.587$

0.868

Table 3.

Discriminant validity HTMT

\begin{tabular}{llccll}
\hline Hypothesis & Path & Path coefficient & $t$ value & $p$ value & Decision \\
\hline H1 & Promotion $\rightarrow$ Awareness & 0.453 & 2.864 & $0.004^{*}$ & Supported \\
H2 & Awareness $\rightarrow$ Connect & 0.559 & 3.371 & $0.001^{*}$ & Supported \\
H3 & Promotion $\rightarrow$ Connect & 0.084 & 0.239 & 0.812 & Not Supported \\
H4 & Awareness $\rightarrow$ Sustainable demand & 0.276 & 2.149 & $0.032^{*}$ & Supported \\
H5 & Connect $\rightarrow$ Sustainable demand & 0.116 & 0.720 & 0.471 & Not Supported \\
H6 & Promotion $\rightarrow$ Sustainable demand & 0.36 & 2.058 & $0.040^{*}$ & Supported
\end{tabular}

Note(s): *Significant at $5 \%$ level of significance

Source(s): Author's own

Table 4.

Hypothesis summary

\begin{tabular}{llr}
\hline & $R^{2}$ & $Q^{2}$ \\
\hline Awareness & 0.228 & 0.102 \\
Connect & 0.372 & 0.212 \\
Sustainable demand & 0.163 & 0.079
\end{tabular}

Source(s) Author's own

Table 5.

Predictive relevance 
IHR

36,2

\section{4}

Itcan be seen that social media promotion activities indeed createawareness amongst people about sustainability ( $t$ value 2.864, path coefficient 0.453 ), thus $\mathrm{H1}$ is supported. It can be seen that creating awareness about sustainability indeed leads to connecting sustainable tourists together (path coefficient 0.559 and $t$ value 3.371 ), thus $\mathrm{H} 2$ is supported. On the other hand, it can be seen that social media promotional activities may not necessarily connect potential sustainable tourists together ( $t$ value 0.239 , path coefficient 0.084 ), thus $\mathrm{H} 3$ is not supported. $\mathrm{H} 4$ indicating that awareness positively impacts the generation of sustainable demand is also supported ( $t$ value 2.149 , path coefficient 0.276 ). It can be seen that merely connecting potential sustainable tourists does not necessarily generate sustainable demand ( $t$ value 0.72 , path coefficient 0.471), thus H5 is not supported. Social media promotion activities are indeed instrumental in creating a sustainable demand amongst tourist ( $t$ value 2.058 , path coefficient 0.36), thus $\mathrm{H} 6$ is supported. A summary of all the hypotheses is given in Table 4.

Predictive power. Predictive power of the structural model in PLS-SEM is checked through endogenous construct's $R^{2}$ and $Q^{2}$ values. These values for all the endogenous latent constructs are shown in Table 5. $R^{2}$ values above the value of 0 are considered relevant for a new or just discovered model (Hair et al., 2017; Chin, 2010). The $R^{2}$ value for awareness is 0.228 , for connect is 0.372 and for sustainable demand is 0.613 . While the values indicate weak to moderate predictive power, it is suggested that $R^{2}$ should be interpreted as per the study's context (Henseler et al., 2009; Hair et al., 2011). The blindfolding $Q^{2}$ values above 0 indicate predictive accuracy of the endogenous constructs. The $Q^{2}$ value for awareness is 0.102 , for connect is 0.212 and for sustainable demand is 0.079 , and thus, it can be said that endogenous latent constructs can predict moderately the exogenous variables (Chin, 2010).

\section{Discussion}

While the concern for sustainability has been a talked about area since 1980s (WCED, 1987), the advent of social media in marketing mix is fairly new. The empirical results show that an Indian tourist gains awareness about sustainable tourism through social media promotion activities and may eventually demand sustainable tourism product and thus indulge in sustainable tourist behaviour. These results are in line with Benckendorff et al. (2014), where it was noted that social media helps tourist to gain awareness about environmental sustainability, as it makes information distribution and access easy. It is due to the transparency that media has now attained through social media channels that prompt this sustainably aware behaviour where questions can be asked and doubts clarified (Carter and Rogers, 2008). Findings suggest that creating awareness about sustainability indeed leads to connecting sustainable tourists together. Similar observation was noted by Chan et al. (2014) as an individual's efforts to build "sustainable social-ecological systems. It can be said that meaning is socially constructed as suggested by Social Information Processing theory.

At the same it can be seen that as much as general use of social media channels connect people, social media promotion activities about sustainability may not actually help the same. It can be concluded that Indian tourists connect with each other through awareness of sustainability and not through social media promotional activities.

Results indicate that awareness positively impacts the generation of sustainable demand. This is in line with the previous literature which notes that "information obtained" (Swarbrooke and Horner, 2007; Miller 2003) and "knowledge" (Chan et al., 2014) as vital aspects of adopting green behaviour.

But the results also indicate that merely connecting tourists may not actually lead to sustainable demand generation. A similar conclusion was drawn by Harris (2006), where it was noted that merely expressing environmental concerns did notalways result in actual behaviour towards environmental products. This may be attributed to the talk of sustainability on social and lifestyle media, which has emerged as a common topic and the "fashionalisation of 
sustainable consumption" (Lundahl, 2014) and there could be a mismatch in actual and perceived behaviour of actual consumption of sustainable products as noted by Harris (2006).

It can be seen that social media promotion activities are indeed instrumental in creating a sustainable demand amongst tourist. Media dependency positively affects purchase intentions which has also been noted in previous studies (Bigné-Alcañiz and Currás-Pérez, 2008; Patwardhan and Yang, 2003). The results are in line with Budeanu (2013), who noted social media can promote sustainable demand in tourism in her study of TripAdvisor.

Strähle and Gräff (2017) also noted that social media plays an active role in promotion and publicity to create awareness and higher attention towards sustainability, which in turn leads to increased sustainable demand.

The conceptual framework proposed, which is on lines of AIDA model, thus, can be said to be effectively making a mark on tourists in terms of building a connection and thus motivating them towards a sustainable demand; this is in lines with previous studies indicating that consumer behaviour about sustainability is shaped through Internet when companies share their sustainability initiatives (Hennig-Thurau and Walsh, 2003; Tsai and Men, 2014).

\section{Implications of the research}

This study provides empirical results on how social media impacts sustainable tourist behaviour and how social media can help in generating sustainable demand. The study adds to the rising interest in understanding the behavioural changes in tourists (Hall, 2016) and provides insights on "the versatility of the topic of relationship between sustainable tourism and marketing" (Font and McCabe, 2017). While ethical consumption is essential to preserve resources, the study of this area of consumer behaviour is "under examined", as majority studies focus on products, very few studies elucidate on encouraging it through social marketing (Newholm and Shaw, 2007). Thus, this study attempts to fill the gap in the literature by proposing a framework for generating sustainable demand amongst tourists so that they are inclined socially and sustainably both through the use of social media.

It is often noted that tourists are unwilling to change their travel behaviour as a result of lack of awareness or due to hesitance of sacrificing (Juvan and Dolnicar, 2014; Miller et al., 2010). This study provides empirical evidence that supports the awareness of sustainability as a means of generating sustainable demand amongst tourists. Knowledge regarding tourism demand helps in the further development of tourism products and its marketing initiatives (Weber, 2019). Thus, it allows tourism players to understand that Indian tourists are open to sustainable tourist practices if enough information is provided to them.

Internet allows users to obtain information about products and brands to its users through various social media such as blogs, forums, wikis content sharing, etc. (HennigThurau and Walsh, 2003; Reilly and Weirup, 2010). Strategies can thus be formulated to target sustainable tourists with sustainable destinations and amenities, so as to attract those tourists who appreciate and commit to the cause of sustainability (López-Sánchez and Pulido-Fernández 2016). Using social media as a promotion tool can help in educating customers (Xiang and Gretzel, 2010) on the various sustainable tourism services they intend to offer, as the results supports the use of social media promotion for generating sustainable demand amongst the tourists. Also, the sustainable tourism providers can make use of promotional activities focussing on building online pro environmental touristbased communities using the user generated contents which can positively lead to adoption of collective social behaviour and sustainable practices (Han et al., 2017). Specifically, the use of short interactive messages can be used for social media promotions, so as to increase "organisation prominence" amongst the green target groups online (Strähle and Gräff, 2017) 
IHR

36,2

\section{6}

While it was noted that different markets react differently to the idea of sustainability, and thus, different markets need to be explored deeper (Weber, 2019); this study attempts to provide a perspective of Indian tourists which not just adds to the literature on Indian tourist behaviour but also provides a viewpoint of the Asian tourists. It also enriches the existing literature on the use of AIDA model for services and tourism specifically which as a theoretical base is unexplored.

It also attempts to sensitise tourists and hospitality players about sustainable tourism. It encourages tourism service providers to build a sustainable competitive advantage by using social media as a platform of promotion and thus, providing tourists with unique, memorable and sustainable touristic experiences (Pine and Gilmore, 1999). Social platforms such as PlanetA can be used for collaborations etc., for promotion and demand generation.

\section{Limitation and scope of future study}

This study takes into account the informational and environmental knowledge aspect of sustainable behaviour adoption by green tourists (Swarbrooke and Horner, 2007; Miller, 2003; Chan et al., 2014). This study draws implications based on the behaviour of Indian tourists and thus the generalisation to other countries may not be as accurate as Indians differ culturally from the world at large.

Even though the study involves different age groups, the mean age is of younger Indian tourists, which is also often considered as the most active users of social media and thus likely to be impacted more. Also, it is believed that these younger green consumers who are already inclined towards sustainability tend to seek more information on ethical issues (Finney, 2014).

The sample size of the study is very small $(n=250)$ and was only checked for variation amongst gender and profession; other aspects such as income and employment (Swarbrooke and Horner, 2007; Miller 2003) have been kept out of the study and thus not included as a part of demographics. More demographic characteristics can be taken into account to study if they play a mediating role in generating sustainable demand as a part of the analysis of this conceptual framework proposed.

Since the model and hypotheses were formed from research gaps, no fundamental comparison point was available for the very same model. Thus, it is suggested that academicians, researchers can take forward the proposed model and make a cross cultural comparison amongst tourists of various countries. Also, it is suggested that the suggested model can be tested for consumption of sustainable products for a meaningful comparison of adoption of sustainable behaviour for products and service and to note if they vary.

\section{References}

Ahuja, M. and Galvin, J. (2003), "Socialization in virtual groups", Journal of Management, Vol. 29, pp. 161-185, doi: 10.1177/014920630302900203.

Ali, A. and Frew, A.J. (2010), "ICT and its role in sustainable tourism development", in Gretzel, U., Law, R. and Fuchs, M. (Eds), Information and Communication Technologies in Tourism 2010, Springer Wien, New York, pp. 479-491.

Ames, M. and Naaman, M. (2007), "Why we tag: motivations for annotation in mobile and online media”, Proc SIGCHI Conference Human factors Computer System, No. 1, pp. 971-980, doi: 10. 1145/1240624.1240772.

Ayeh, J.K. (2015), “Travellers' acceptance of consumer-generated media: an integrated model of technology acceptance and source credibility theories", Computers in Human Behavior, Vol. 48, pp. 173-180.

Bach, J. and Stark, D. (2004), "Link, search, interact the co-evolution of NGOs and interactive technology", Theory, Culture and Society, Vol. 21 No. 3, pp. 101-117. 
Batat, W. and Prentovic, S. (2014), "Towards viral systems thinking: a cross-cultural study of sustainable tourism ads", Kybernetes, Vol. 43 Nos 3/4, pp. 529-546.

Benckendorff, P.J., Sheldon, P.J. and Fesenmaier, D.R. (2014), Tourism Information Technology, CABI, Wallingford.

Bigne-Alcañiz, E.Y. and Currás-Pérez, R. (2008), Influye la imagen de responsabilidad social en la intención de compra? el papel de la identificación del consumidor con la empresa, Universia Business Review, Madrid, Tercer Trimestre.

Bray, J., Johns, N. and Kilburn, D. (2011), "An exploratory study into the factors impeding ethical consumption", Journal of Business Ethics, pp. 597-608, doi: 10.1007/s10551-010-0640-9.

Budeanu, A. (2013), "Sustainability and tourism social media", in Munar, A.M., Gyimothy, S. and Liping, C. (Eds), Tourism Social Media: Transformations in Identity, Community and Culture, Emerald, Bingley, p. 87103.

Buhalis, D. and Law, D. (2008), "Progress in Information Technology and tourism management: 20 years on and 10 years after the internet - the state of e-tourism research", Progress in Tourism Management, Vol. 29 No. 4, pp. 609-623.

Buhalis, D. and Licata, M.C. (2002), "The future eTourism intermediaries", Tourism Management, Vol. 23 No. 3, pp. 207-220.

Bustam, T.D., Buta, N. and Stein, T.V. (2012), "The role of certification in international ecotourism operators' internet promotion of education", Journal of Ecotourism, Vol. 11 No. 2, pp. 85-101, doi: 10.1080/14724049.2012.683005.

Carter, C. and Rogers, D. (2008), "A framework of sustainable supply chain management: moving toward new theory", International Journal of Physical Distribution and Logistics Management, Vol. 38, pp. 360-387, doi: 10.1108/09600030810882816.

Chan, K.M.A., Satterfeld, T. and Goldstein, J. (2012), "Rethinking ecosystem services to better address and navigate cultural values”, Ecological Economics, Vol. 74, pp. 8-18, doi: 10.1016/j.ecolecon. 2011.11.011.

Chan, E.S.W., Hon, A.H.Y., Chan, W. and Okumus, F. (2014), "What drives employees' intentions to implement green practices in hotels? The role of knowledge, awareness, concern and ecological behavior", International Journal of Hospitality Management, Vol. 40 July, pp. 20-28.

Charter, M. (1992), Greener Marketing: A Responsible Approach to Business, Greenleaf Publishing, Sheffield.

Cheng, M., Wong, I.A., Wearing, S. and McDonald, M. (2016), "Ecotourism social media initiatives in China”, Journal of Sustainable Tourism, Vol. 25 No. 3, pp. 416-432.

Chin, W.W.(2010), "How to write up and report pls analyses”, in Esposito Vinzi, V., Chin, W.W., Henseler,J. and Wang, H. (Eds), Handbook of Partial Least Squares, Springer, Berlin, Heidelberg, pp. 655-690.

Chung, J. and Buhalis, D. (2008), "Web 2.0: a study of online travel community", Information and Communication Technologies in Tourism, pp. 267-282, doi: 10.1007/978-3-211-77280-5_7.

Cohen, S.A., Prayag, G. and Moital, M. (2014), "Consumer behaviour in tourism: concepts, influences and opportunities”, Current Issues in Tourism, Vol. 17 No. 10, pp. 872-909, doi: 10.1080/13683500.2013. 850064.

Cummings, J.N., Butler, B. and Kraut, R. (2002), "The quality of online social relationships", Communications of the ACM, Vol. 45 No. 7, pp. 103-108.

Deloitte (2011), "Hospitality 2015: tourism, hospitality, and leisure trends", available at: http://www. barcelonahotels.org/private/biblioteca/doc/Hospitality_2015.pdf.

Derungs, C. and Purves, R.S. (2016), "Characterising landscape variation through spatial folksonomies", Applied Geography, Vol. 75, pp. 60-70, doi: 10.1016/j.apgeog.2016.08.005.

Diaz, A. (2015), "Defining social media", available at: https://www.boundless.com/.

Falk, J.H., Ballantyne, R., Packer, J. and Benckendorff, P. (2012), "Travel and learning: a neglected tourism research area", Annals of Tourism Research, Vol. 39 No. 2, p. 908927. 
IHR

36,2

\section{8}

Fien, J., Calder, M. and White, C. (2010), "Sustainable tourism (module 16)", Teaching and Learning for a Sustainable Future, UNESCO.

Finney, S.L. (2014), "Encouraging sustainable consumption: an exploration of con-sumer behaviour", The Marketing Review, Vol. 14 No. 2, pp. 189-203.

Font, X. and McCabe, S. (2017), "Sustainability and marketing in tourism: its contexts, paradoxes, approaches, challenges and potential", Journal of Sustainable Tourism, Vol. 25 No. 7, pp. 869-883.

Garcia, S.M., Tor, A. and Schiff, T.M. (2013), "The psychology of competition: a social comparison perspective", Perspectives on Psychological Science, Vol. 8 No. 6, 634650.

Germann Molz, J. (2012), Travel Connections: Tourism, Technology and Togetherness in a Mobile World, Routledge, London.

Gliozzo, G., Pettorelli, N. and Haklay, M. (2016), "Using crowdsourced imagery to detect cultural ecosystem services: a case study in South Wales, UK", Ecology and Society, Vol. 21 No. 3, p. 6, doi: 10.5751/ES-08436-210306f.

Gossling, S. and Stavrinidi, I. (2015), "Social networking, mobilities, and the rise of liquid identities", Mobilities, pp. 1-21, doi: 10.1080/17450101.2015.1034453.

Grant, J. (2007), "Ist «Grün» nur ein gesellschaftlicher Tick?", GDI Impuls, Wissensmagazin für Wirtschaft, Gesellschaft, Handel, nrZurich, Vol. 73, pp. 9-12, available at: https://ecitydoc.com/ download/gdiimpuls-gottlieb-duttweiler-institute_pdf.

Guerrero, P., Møller, M.S., Olafsson, A.S. and Snizek, B. (2016), "Revealing cultural ecosystem services through instagram images: the potential of social media volunteered geographic information for urban green infrastructure planning and governance”, Urban Plan, pp. 105-131, doi: 10.17645/ up.v1i2.609.

Hair, J.F., Ringle, C.M. and Sarstedt, M. (2011), "PLS-SEM: indeed a silver bullet", Journal of Marketing Theory and Practice, Vol. 19 No. 2, pp. 139-152.

Hair, J.F. Jr, Hult, G.T., Ringle, C. and Sarstedt, M. (2013a), A Primer on Partial Least Squares Structural Equation Modeling (PLS-SEM), Sage Publications, Thousand Oaks.

Hair, J.F., Ringle, C.M. and Sarstedt, M. (2013b), "Partial least squares structural equation modeling: rigorous applications, better results and higher acceptance", Long Range Planning, Vol. 46 Nos 1/2, pp. 1-12.

Hair, J., Sarstedt, M., Hopkins, L. and Kuppelwieser, V. (2014), "Partial least squares structural equation modeling (PLS-SEM): an emerging tool for business research", European Business Review, Vol. 26, pp. 106-121, doi: 10.1108/EBR-10-2013-0128.

Hair, J.F., Hult, G.T.M., Ringle, C.M. and Sarstedt, M. (2017), A Primer on Partial Least Squares Structural Equation Modeling (PLS-SEM), Sage, Thousand Oaks, CA.

Hall, C.M. (2016), "Intervening in academic interventions: framing social marketing's potential for successful sustainable tourism behavioural change", Journal of Sustainable Tourism, Vol. 24 No. 3, pp. 350-375.

Han, W., McCabe, S., Wang, Y. and Choong, A.Y.L. (2017), "Evaluating user-generated content in social media: an effective approach to encourage greater pro-environmental behavior in tourism", Journal of Sustainable Tourism, Vol. 26 No. 4, pp. 600-614, doi: 10.1080/09669582.2017.1372442.

Hardeman, G., Font, X. and Nawijn, J. (2017), "The power of persuasive communication to influence sustainable holiday choices: appealing to self-benefits and norms", Tourism Management, Vol. 59, pp. 484-493.

Harris, P.G. (2006), "Environmental perspectives and behavior in China synopsis and bibliography", Environment and Behavior, Vol. 38 No. 1, pp. 5-21.

Hausmann, A., Toivonen, T., Slotow, R., Tenkanen, H., Moilanen, A., Heikinheimo, V. and Di Minin, E. (2018), "Social media data can be used to understand tourists' preferences for naturebased experiences in protected areas", Conservation Letters, Vol. 11, pp. 1-10. 
Hays, S., Page, S.J. and Buhalis, D. (2013), "Social media as a destination marketing tool: its use by national tourism organisations", Current Issues in Tourism, Vol. 16 No. 3, pp. 211-239.

Hennig-Thurau, T. and Walsh, G. (2003), "Electronic word-of-mouth: motives for and consequences of reading customer articulations on the internet", International Journal of Electronic Commerce, Vol. 8, pp. 51-74.

Henseler, J., Ringle, C.M. and Sinkovics, R.R. (2009), "The use of partial least squares path modeling in international marketing", New Challenges to International Marketing, Emerald Group Publishing, Bingley, pp. 277-319.

Henseler, J., Ringle, C. and Sarstedt, M. (2015), "A new criterion for assessing discriminant validity in variance-based structural equation modeling", Journal of the Academy of Marketing Science, Vol. 43, pp. 115-135, doi: 10.1007/s11747-014-0403-8.

Higgins-Desbiolles, F. (2017), "Sustainable tourism: sustaining tourism or something more?", Tourism Management Perspectives, pp. 1-7, ISBN: 2211-9736, doi: 10.1016/j.tm017.11.017.

Hvass, K.A. and Munar, A.M. (2012), "The takeoff of social media in tourism", Journal of Vacation Marketing, Vol. 18 No. 2, pp. 93-103.

Johnson, L.A. (2014), "Connecting sustainability reporting and social media", National Provisioner, Vol. 228 No. 1, pp. 30-35.

Johnston, R. and Tyrrell, T. (2005), "A dynamic model of sustainable tourism", Journal of Travel Research, Vol. 44, pp. 124-134, doi: 10.1177/0047287505278987.

Jun, S., Vogt, C. and MacKay, K. (2007), "Relationships between travel information search and travel product purchase in pretrip contexts”, Journal of Travel Research, Vol. 45, pp. 266-274, doi: 10. 1177/0047287506295945.

Juvan, E. and Dolnicar, S. (2014), "The attitude-behaviour gap in sustainable tourism", Annals of Tourism Research, Vol. 48, pp. 76-95.

Kane, K., Chiru, C. and Ciuchete, S.G. (2012), "Exploring the eco-attitudes and buying behaviour of Facebook users", Amfiteatru Economic, Vol. XIV No. 31, pp. 157-171.

Kaplan, A. and Haenlein, M. (2010), "Users of the world, unite! The challenges and opportunities of social media”, Business Horizons, Vol. 53, pp. 59-68, doi: 10.1016/j.bushor.2009.09.003.

Kojima, T., Kimura, T., Yamaji, M. and Amasaka, K. (2010), "Proposals and development of the direct mail method 'PMCI-DM' for effectively attracting customers", International Journal of Management and Information Systems, Vol. 14 No. 5, pp. 15-21.

Kolandai-Matchett, K. (2009), "Mediated communication of 'sustainable consumption' in the alternative media: a case study exploring a message framing strategy", International Journal of Consumer Studies, Vol. 33 No. 2, pp. 113-125, doi: 10.1111/j.1470-6431.2009.00754.x.

Kotler, P., Armstrong, G. and Cunningham, M.H. (2005), Principles of Marketing, Pearson Prentice Hall, Toronto.

Lai, P.-H. and Shafer, S. (2005), "Marketing ecotourism through the internet: an evaluation of selected ecolodges in Latin America and the caribbean", Journal of Ecotourism, Vol. 4, pp. 143-160, doi: 10.1080/JET.v4.i3.pg143.

Langley, D. and van den Broek, T. (2010), "Exploring social media as a driver of sustainable behaviour: case analysis and policy implications", available at: http://www.tno.nl/downloads/ Langley \%20en \%20Van \%20den \%20Broek \%20IPP\%202010\%20paper \%20-\%20final $\%$ 20version \%2013082010.pdf.

Lewis, B.R. (1989), "Quality in the service sector: a review", International Journal of Bank Marketing, Vol. 7 No. 5, pp. 4-12, doi: 10.1108/02652328910134590.

López-Sánchez, Y. and Pulido-Fernández, J.I. (2016), "In search of the pro-sustainable tourist: a segmentation based on the tourist 'sustainable intelligence", Tourism Management Perspectives, Vol. 17, pp. 59-71, doi: 10.1016/j.tm015.12.003. 
IHR

36,2

390

Luck, E. and Ginanti, A. (2013), "Online environmental citizenship: blogs, green marketing and consumer sentiment in the 21st century", Electronic Green Journal, Vol. 1 No. 35, pp. 1-26.

Lundahl, O. (2014), "Fashionalising sustainable consumption in lifestyle media", Advances in Consumer Research, Vol. 42, pp. 343-347.

Manfredo, M.J., Teel, T.L. and Dietsch, A.M. (2016), "Implications of human value shift and persistence for biodiversity conservation”, Conservation Biology, Vol. 30, pp. 287-296, doi: 10.1111/cobi.12619.

Mauri, A.G. and Minazzi, R. (2013), "Web reviews influence on expectations and purchasing intentions of hotel potential customers", International Journal of Hospitality Management, Vol. 34, pp. 99-107.

Michaelson, D. and Stacks, D.W. (2011), "Standardization in public relations measurement and evaluation", Public Relations Journal, Vol. 5 No. 2, pp. 1-22.

Milano, R., Baggio, R. and Piattelli, R. (2011), "The effects of online social media on tourism websites", Proceedings of the ENTER, Innsbruck, Austria, 26-28 January, pp. 471-483, 9.

Miller, G.A. (2003), "Consumerism in sustainable tourism: a survey of UK consumers", Journal of Sustainable Tourism, Vol. 11 No. 1, p. 17.

Miller, G., Rathouse, K., Scarles, C., Holmes, K. and Tribe, J. (2010), "Public understanding of sustainable tourism", Annals of Tourism Research, Vol. 37 No. 3, pp. 627-645.

Munar, A. (2011), “Tourist-created content: rethinking destination branding”, International Journal of Culture, Tourism and Hospitality Research, Vol. 5, pp. 291-305, doi: 10.1108/17506181111156989.

Newholm, T. and Shaw, D. (2007), "Studying the ethical consumer: a review of research", Journal of Consumer Behaviour, Vol. 6 No. 5, pp. 253-270.

Parra Lopez, E., Bulchand-Gidumal, J., Taño, D. and Armas, R.J. (2011), "Intentions to use social media in organizing and taking vacation trips", Computers in Human Behavior, Vol. 27, pp. 640-654, doi: 10.1016/j.chb.2010.05.022.

Patwardhan, P. and Yang, J. (2003), "Internet dependency relations and online consumer behavior", Journal of Interactive Advertising, Vol. 3, pp. 57-69, doi: 10.1080/15252019.2003.10722074.

Peattie, K. (1995), Environmental Marketing Management: Meeting the Green Challenge, Pitman, London.

Pentina, I. and Tarafdar, M. (2014), "From 'information' to 'knowing': exploring the role of social media in contemporary news consumption", Computers in Human Behavior, Vol. 35, pp. 211-223, doi: 10.1016/j.chb.2014.02.045.

Pine, B.J. and Gilmore, J.H. (1999), The Experience Economy: Work Is Theatre and Every Business Is a Stage, Harvard Business School Press, Boston.

Rasche, A. (2010), “Collaborative governance 2.0", Corporate Governance International Journal of Business in Society, pp. 1-19, doi: 10.1108/14720701011069713.

Rawal, P. (2013), "AIDA marketing communication model: stimulating a purchase decision in the minds of the consumers through a linear progression of steps", IRC's International Journal of Multidisciplinary Research in Social and Management, Vol. 1, pp. 37-44.

Reilly, A. and Hynan, K. (2014), Corporate Communication, Sustainability, and Social Media: It's Not Easy (Really) Being Green, Elsevier, Amsterdam. doi: 10.1016/j.bushor.2014.07.008.

Reilly, A. and Weirup, A. (2010), "Sustainability initiatives, social media activity, and organizational culture: an exploratory study", Journal of Sustainability and Green Business, Vol. 1, pp. 1-15.

Rex, E. and Baumann, H. (2007), "Beyond ecolabels: what green marketing can learn from conventional marketing", Journal of Clean Production, Vol. 15 No. 6, pp. 567-576, doi: 10.1016/j. jclepro.2006.05.013.

Ringle, C.M., Wende, S. and Becker, J.-M. (2015), “SmartPLS 3. Bönningstedt: SmartPLS”, available at: http://www.smartpls.com.

Safko,L. andBrake,D.K.(2009), The SocialMediaBible: Tactics, Tools, and Strategies for Business Success, Wiley, Hoboken, NJ. 
Sarkar, S.K., Au, N. and Law, R. (2014), "Analysing ecotourists' satisfaction in socialisation and knowledge sharing intentions via social media", in Xiang, Z. and Tussyadiah, I. (Eds), Information and Communication Technologies in Tourism 2014, Springer International Publishing, 2013, pp. 313-326, ISBN 978-3-211-99406-1.

Sarkar, S.K., Au, N. and Law, R. (2017), "Analysing the effect of value in online communities on satisfaction in online socialisation and knowledge-sharing intentions of eco - Tourists", in de Pablos, P.O. (Ed.), Managerial Strategies and Solutions for Business Success in Asia, IGI Global, New York, pp. 28-39.

Simpson, M.C., Gössling, S., Scott, D., Hall, C.M. and Gladin, E. (2008), Climate Change Adaptation and Mitigation in the Tourism Sector: Frameworks, Tools and Practices, UNEP, University of Oxford, UNWTO, WMO, Paris, available at: http://www.unep.fr/shared/publica-tions/pdf/ dtix1047xpa-climatechange.pdf.

Sparks, B.A., Perkins, H.E. and Buckley, R. (2013), "Online travel reviews as persuasive communication: the effects of content type, source, and certification logos on consumer behavior", Tourism Management, Vol. 39, pp. 1-9.

Stevens, J.P. (2012), Applied Multivariate Statistics for the Social Sciences, 5th ed., Routledge, London.

Strähle, J. and Gräff, C. (2017), “The role of social media for a sustainable consumption”, in Strähle, J. (Ed.), Green Fashion Retail, Springer Series in Fashion Business. doi: 10.1007/978-981-10-2440-5_12.

Swarbrooke, J. and Horner, S. (2007), Consumer Behaviour in Tourism, 2nd ed., ButterworthHeinemann, Burlington, MA.

Tapon, F. and Leighton, T. (1991), Green as strategy: Lessons from the chemical industry (Cahiers de Recherche No. 1991-17), Department of Economics, University of Guelph, Guelph.

Tsai, W. and Men, L. (2014), "Consumer engagement with brands on social network sites: a crosscultural comparison of China and the USA", Journal of Marketing Communications, Vol. 23, pp. 1-20, doi: 10.1080/13527266.2014.942678.

UNWTO (2000), Tourism Highlights, 2nd ed., August, World Tourism Organization.

UNWTO (World Tourism Organization) (2017), UNWTO Tourism Highlights, World Tourism Organization, Madrid.

UNWTO (World Tourism Organization) (2010), ASEAN Integration and its Impact on Tourism, World Tourism Organization, Madrid.

Vinzi, V.E., Trinchera, L. and Amato, S. (2010), "PLS path modeling: from foundations to recent developments and open issues for model assessment and improvement", in Vinzi, V.E., Chin, W.W., Henseler, J. and Wang, H. (Eds), Handbook of Partial Least Squares, Springer Handbooks of Computational Statistics, Springer-Verlag Berlin Heidelberg, pp. 47-82.

WCED (1987), Our Common Future, Oxford University Press, New York, NY.

Weber, L. (2009), Marketing to the Social Web: How Digital Customer Communities Build Your Business, John Wiley \& Sons, Hoboken.

Weber, F. (2019), "Demand for sustainable tourism”, in Lund-Durlacher, D., Dinica, V., Reiser, D. and Fifka, M.S. (Eds), Corporate Sustainability and Responsibility in Tourism, CSR, Sustainability, Ethics and Governance. doi: 10.1007/978-3-030-15624-4_16.

Weeden, C. (2013), Responsiyoungble and Ethical Tourist Behaviour, Routledge, London.

Wehrli, R., Egli, H., Lutzenberger, M., Pfister, D., Schwarz, J. and Stettler, J. (2011), Is There Demand for Sustainable Tourism? Study for the World Tourism Forum Lucerne 2011, ITW Working Paper Series Tourism 001/2011, Short Version, Lucerne University of Applied Sciences and Arts, Lucerne.

Weinberg, T. (2009), The New Community Rules: Marketing on the Social Web, O'Reilly Media, Sebastopol, CA.

Wijaya, B.S. (2015), "The development of hierarchy of effects model in advertising", International Research Journal of Business Studies, Vol. 5 No. 1, pp. 73-85. 
IHR

36,2

392

WTO (2001), "The concept of sustainable tourism", available at: http://www.world-tourism.org/ sustainable/concepts.htm.

World Tourism Organization (2005), UNWTO Tourism Highlights, 2005 Edition, wto, Madrid, doi: $10.18111 / 9789284411900$.

Xiang, Z. and Gretzel, U. (2010), "Role of social media in online travel information search", Tourism Management, Vol. 31 No. 2, pp. 179-188.

Zapico, J., Brandt, N. and Turpeinen, M. (2010), "Environmental metrics: the main opportunity from ICT for industrial ecology", Journal of Industrial Ecology, Vol. 14, doi: 10.1111/j.1530-9290.2010. 00272.x.

Zhang, M., Yu, W. and Yuan, J. (2011), "Embracement of E-tourism in ecotourism: a case study of tourism websites for galapagos", Computer and Information Science (ICIS), 2011 IEEE/ACIS 10th International Conference on IEEE, pp. 171-176.

Zolkepli, I.A. and Kamarulzaman, Y. (2015), "Social media adoption: the role of media needs and innovation characteristics", Computers in Human Behavior, Vol. 43, pp. 189-209, doi: 10.1016/j. chb.2014.10.050.

\section{Further reading}

Ali, A. and Frew, A.J. (2014), "ICT and sustainable tourism development: an innovative perspective", Journal of Hospitality and Tourism Technology, Vol. 5 No. 1, p. 216, doi: 10.1108/JHTT-122012-0034.

ASEAN (2015), ASEAN Tourism Strategic Plan 2016-2025, The Association of Southeast Asian Nations, Jakarta.

ASEAN Integration Report (2015), available at: https://asean.org/asean-integration-report-2015-4/.

Calcagni, F., Terra, A.T.M., Connolly, J.J.T. and Langemeyer, J. (2019), "Digital co-construction of relational values: understanding the role of social media for sustainability", Sustainability Science, Special feature: theoretical traditions in social values for sustainability. doi: 10.1007/ s11625-019-00672-1.

Ding, Y. and Chai, K.-H. (2009), "Quality and customer satisfaction spillovers in the mobile telecoms industry”, Service Science, Vol. 1, doi: 10.1109/IEEM.2009.5373012.

Hennig-Thurau, T., Gwinner, K., Walsh, G. and Gremler, D. (2003), "Electronic word of mouth: motives for and consequences of reading customer articulations on the internet", International Journal of Electronic Commerce/Winter, Vol. 4, pp. 51-74.

Hlee, S., Cheng, A., Koo, C. and Kim, T. (2017), "The difference of information diffusion for Seoul tourism destination according to user certification on Sina Weibo: through data crawling method", International Journal of Tourism Sciences, Vol. 17 No. 4, pp. 262-275.

Jacobsen, J. and Munar, A. (2012), "Tourist information search and destination choice in a digital age", Tourism Management Perspectives, Vol. 1, pp. 39-47, doi: 10.1016/j.tm011.12.005.

Kwok, W.T. (2013), "Indoor air quality and its effects on humans - a review of challenges and developments in the last 30 years", Energy and Buildings, Vol. 130, pp. 637-650, 2016, doi: 10. 1016/j.enbuild.chan.08.071.

Stacks, D. and Michaelson, D. (2009), "Exploring the comparative communications effectiveness of advertising and public relations: a replication and extension of prior experiments", Public Relations Journal, Vol. 3, pp. 1-22.

Tsai, W. and Men, L. (2013), "Motivations and antecedents of consumer engagement with brand pages on social networking sites", Journal of Interactive Advertising, Vol. 13, pp. 76-87, doi: 10.1080/ 15252019.2013.826549.

You, Y. and Pekkola, S. (2000), "Supporting awareness of other people on the WWW: framework and example”, PACIS 2000 Proceedings, Vol. 4, available at: https:/aisel.aisnet.org/pacis2000/4. 
About the author

Shruti Gulati is a Ph.D Scholar at Department of Commerce, Delhi School of Economics University of Delhi. She is also working as an Assistant Professor at Shaheed Bhagat Singh College, University of Delhi. She was awarded Lady Shri Ram College Colors Awards in her graduation and Central Student's Scholarship in her post graduation. She has presented papers at various National and International Conferences and Seminars, some of which have also been recognized as "Best Paper". She has published several papers in journals of repute. Her areas of interest include Consumer Behaviour, Hospitality and Tourism Management, Social Media and Marketing. Shruti Gulati can be contacted at: gulati_shruti@ yahoo.co.in
Social and sustainable

For instructions on how to order reprints of this article, please visit our website: 